University of Louisville

ThinkIR: The University of Louisville's Institutional Repository

$1-1927$

\title{
The education of the natural man : a study in the political philosophy of J. J. Rousseau.
}

Esther E. Mason

University of Louisville

Follow this and additional works at: https://ir.library.louisville.edu/etd

\section{Recommended Citation}

Mason, Esther E., "The education of the natural man : a study in the political philosophy of J. J. Rousseau." (1927). Electronic Theses and Dissertations. Paper 911.

https://doi.org/10.18297/etd/911

This Master's Thesis is brought to you for free and open access by ThinkIR: The University of Louisville's Institutional Repository. It has been accepted for inclusion in Electronic Theses and Dissertations by an authorized administrator of ThinkIR: The University of Louisville's Institutional Repository. This title appears here courtesy of the author, who has retained all other copyrights. For more information, please contact thinkir@louisville.edu. 


\title{
UNTVERSITY OF LOUISVILLE
}

THE EDUCATION OF THE NATURAL MAN:

A STUDY IN THE POLITICAL PHILOSOPHY OF

J. J. ROUSSEAU

\author{
A Dissertation \\ Submitted to the Faculty \\ Of the Graduate School of the University of Louisville \\ In Partial Fulfillment of the \\ Requirements for the Degree \\ Of Naster of Arts
}

Department of History

By

ESTHER E. MASON 
"God makes all things good; man meddles with them and they become evil. He forces one soil to yield the products of another, one tree to bear another's fruit. He confuses and confounds time, place, and natural conditions. He mutilates his dog, his horse, and his slave. He destroys and defaces all things; he loves all that is deformed and monstruous; he will have nothing as nature made it, not even man himself, who must learn his paces like a saddle-horse, and be shaped to his master's taste like the trees in his garden." (1.)

In these, the opening words of Finile, Rousseau admits us to a knowledge of one of the prineiples of his thought. Everything is good, he thinks, as it comes from the hand of God. It becomes bad through the interference of man with the work of nature. We might assume, then, that the interference is bad, and that man was better, more virtuous, before he was interfered with, or educated. And as a matter of fact Rousseau found some such answer to the problem when it first presented itself to him. In Fmile he finds another and more practical solution, that of making man's interference with nature beneficial, rather than harmful, to himself. This solution is possible, he thinks, by educating man in such a way as to allow him the greatest possible freedom to follow his own desires, and the greatest possiblo natural development. In other words, he holds up the natural as an ideal to be pursued, and he devotes the whole of the Emile to a complete plan for the pursuit of that ideal in the education of man.

It becomes apparent after even a superficial examination, and indeed almost from the nature of the case, that we are dealing with two factors, the subject (or object) of the educative plan, and the process itself. To Rousseau the subject was a natural man before

1. The opening paragraph of Emile. I have used the translation by Barbara Foxley for the Everyman edition. 
he was acted upon by the educative process. That concept never changed for Rousseau. Before the man came in contact with any civilizing or educating influence, he was what nature had made him. Therefore he was natural. It is a line of argument, which, once indulged in, is difficult to escape. Yet it is also difficult to see why it should heve been indulged in at all. Except, of course, that morbidity is conducive to an examination of the obvious. And Rousseau was morbid. The idea itself does not appear to have come into being with the Emile. Insofar as Rousseau had written anything up to the time of the writing of Emile he had dealt to some extent with nature and with the educative process, if not olearly and definitely, then by implication. Always there is discernible at the back of his mind the double postulate that man is by nature good, and that his natural goodness is superior to anything which society may make of him. It behooves us, then, to make some examination of Rousseau's conception of the natural man and of his theory of the education of that man in civilized society. 
In point of time the idea of natural man presented Itself to Rousseau's consideration later than the problem of education. The first essay on education, however, was the Projet pour I'Education of $\mathbf{M}$. de Ste.-Marie, a memorandum written for the father of one of his pupils when Rousseau gave up, after a year's struggle, his one and only attempt to teach. The paper was simply a more or less practical scheme for the education of a definite individual and was written before the author had given any philosophical consideration to the problem of education. When Rousseau's Iiterary career began, surprisingly enough, eight years later, it began with a consideration of natural man. In 1749 the Academy of Dijon offered a prize for an essay on whether the arts and sciences had contributed to improve morals. With the answer to that question ${ }^{3}$ Rousseau began the discussion of a problem which was to occupy him the rest of his life.

As the Discourse on the Arts and Sciences was the firgt expression of Rousseau's idea of natural man, so it is less definite, less coherent than later essays which deal with the same subject, and so too it is indicative of the line that the

1. 1741. Rousseau was then tutor for the two sons of Bonnot de Mably, of whom "M. de Ste.-Marle" was the elder.

2. Rousseau was thirty -seven years old and his previous efforts at writing had been utterly unsuccessful.

3. For an account of Rousseau's writing of the essay, see Confessions, Book VIII. 
author was to follow in subsequent essays. Indeed the first Discourse assumes much more than it says about the natural man. The essay is built around the assumption that man existed before civilization. Before civilization came to man he was happler than he now is, for although he had none of the benefits or pleasures of civilization, nelther did he have any of its disadvantages. Rousseau assumes this to be true, and, without discussing it at length proceeds to show how the development of the arts and sciences has contributed to man's unhappiness. The process is not interesting to us, and contributes little to the discussion of natural man. But it is interesting to note that man's original condition is described as "that happy ignorance in which eternal wisdom has placed us". It is more than Interesting to contemplate the picture Rousseau paints of the man who realizes his unhappy condition and prays God to restore to him his lost "Ignorance, innocence, and poverty"."

These remarks, taken together with the way in which he distinguishes civilization from nature would seem to indicate that Rousseau considered the state of nature to be radically different from that of civilization, and that the natural man was therefore the savage man. This is a distinction which Rousseau does not make and upon which, therefore, we

1. Oeuvres 13 p. 60
2. Oeuvres 13 p. 85 
cannot insist. In the first place, it is assumed rather than stated that civilization is the opposite of the state of nature. But the assumption is the basis for the exposition of the way in which the arts and sciences have injured man's happy natural condition. There, too, what Rousseau describes is simply the natural condition of man. We can only say that that condition, as he describes it, is the condition of a savage, or rather a pre-savage creature.

All that we can falrly say of the natural man of the Pirst Discourse is that he was an uncivilized or pre-civilized creature dwelling in a blessed state of "1gnorance, innocence, and poverty". The Discourse does not lend 1tself to further analysis, for it is confused and badly written and indicates nothing so clearly as it indicates the murky state of mind in which it was composed. But the wide attention which the essay recelved and the number of challenges it met forced the author to think further along the same line and to clear up his thoughts. Indeed opposition helped the development of his thoughts so much, that it is a pity, from our point of view at least, that his antagonists took issue on minor points rather than on principles. Even with such a stimulation, however,

1. I shall use pre-savage rather than savage to describe this man because he has no social institutions whatever. Savages, as I understand the term, have some.

2. I know of four--those of M. Bordes, M. Gautier (1751), and the King of Poland, and one which was written by "un Academicien de Dijon" who 1s, so far as I know, anonymous. 
Rousseau's thought becomes more and more clear, and when he next writes on the subject his work is much more definite and coherent.

Rousseau's replies to his critics, important as they must have been in the early unfolding of his thought, yet contribute relatively little to our knowledge of that thought. In the Reply to the King of Poland, for instance, he occuples himself with such toples as the difference between the effect of knowledge upon the race and upon the individual. Science, he thinks, need not corrupt all individuals although it has corrupted nations. Sclence must necessarlly have been bad for man, since man's spirit is too limited to enable him to make good use of 1t. Here he gets into a discussion of the endowments of his natural man. Although he has too little ability and too much passion to make good use of the sciences, he has recelved all the mental equipment necessary for a study of his duty. Here we have a definite step in the development of what afterward became an Important phase in the concept of natural man. Duty and morality are henceforth of paramount importance, and in any doubtful cases they are supreme over reason, even though Rousseau sought a rational basis for his thought.

1.V. 13. pp. 121-169.

2. Reponse a Roi de Pologne V. 13 pp. 130

3. Ibid. pp. 127

4. Loc. eit. 
Aside from these considerations there is in this essay a distinction which bears on the last point and which is certainly curious and perhaps important. Rousseau had spoken in the Discours sur les Arts et Sciences of man's original happy 1gnorance. Such a speech was not understood in an age which thought itself enlightened and which in time of stress appealed to reason. So Rousseau's statement was attacked as untrue. Rousseau's reply is interesting. There are two sorts of 1gnot rance. One of them is flerce, brutish, and debasing, and it is evidently this which his opponents have in mind. But "there is another sort of reasonable ignorance which consists in limiting its curiosity to the extent of the faculties which one has received; a modest ignorance which springs from an intense love of virtue, and inspires only indifference for everything which is not worthy of filling man's heart, and which contributes nothing to improve a sweet and precious ignorance, the treasure of a soul pure and self-content-.-." " Here is something different from the primitive ignorance and innocence described in the first Discourse. Here is a rational, self-conscious ignorance, which is intimately linked with virtue. Man's original 1gnorance is still happy and still good, but it has become rationally and intentionally happy and good. The paradox involved is less important to Rousseau than us, for Rousseau was a sort of mystic

1. Ibid. pp. 163-164. 
and placed the emphasis on the morality rather than the logic of the case.

In the reply to $\mathbb{M}$. Bordes Rousseau has more to say of this 1gnorance. "Ignorance is not an obstacle to e1ther good or evil;" he says, "1t is simply the natural condition of man." In a footnote to the same passage he scoffs at the eritics who cite the vices of ignorant people. "If science necessarily engenders vice, does it follow that ignorance necessarily engenders virtue?" he asks. These remarks contribute nothing to the 1dea expressed in the first Discourse. They simply serve to show that Rousseau was aware of the position he had taken, and was becoming able to defend 1t. He makes a great step when he hews away the unnecessary and superfluous and permits the case to rest on 1ts own merits. It is possible, if one is surf1elently clever to establish a logical justification for almost anything. That is what Rousseau was beginning to do, not consclously now, perhaps, though he was soon to be conscious of his 4

attitude. And he was more able than the mere logician for he was armed with a great faith.

The most interesting idea developed in the reply to

1. Derniere Reponse de J. J. Rousseau V. 13. pp. 171-224.

2. Ib1d. p. 181 .

3. Ibia. p. 181 , note.

4. See the Discours sur... I'Inegalite. V. 2. p. 
M. Bordes is that of the original and natural goodness of man. It had been talked about in the first Discourse. In the Elghteenth Century men, at least those men who took 1ssue with Rousseau, belleved in original sin. Rousseau's position was therefore severely attacked, but the opposition seemed to strengthen rather than to weaken 1t, and the idea which was mentioned in the first Discourse, and elaborated first in the reply to $\mathbb{M}$. Bordes and later in the second D1scourse, became the underlying principle of Emile. When it appears in the reply to M. Bordes, the ldea is already well out of its infancy. Rousseau defends it first by reference to history, and second by logic. It is not enough, he says, to say that man is naturally bad because the first man was bad. History proves the contrary, but unfortunately Rousseau does not cite his proof. Instead he has recourse to logic. There was no chance for man to be evil before there was any property or any slavery. Therefore man was good before these things happened. Of course what Rousseau is doing here is proving that men are naturally good because the first men were good, but he does not realize that he is defeating one of his arguments by the other. The discrepancy is perhaps explained by Rousseau's note on the passage. If man is naturally evil the sclences will make him worse, whereas if he is naturally good they will not make him better. For when a people is able to

1. Derniere Reponse -- p. 190. V. 13.

2. Derniere Reponse -- p. 191. V. 13. 
cultivate the sciences it marks the beginning of a ruin which the sclences will hasten. For "there the vice of the constltution does all the evil which that of nature could have done." Here we have a distinction between constitution and nature which shows clearly that constitution refers to the inner"nature" of man and nature to something outside of him. Rousseau frequentIy uses nature in such a way that we can read for it constitution, but usually he uses it in the other sense. Nature to h1m frequently means universal order, and not infrequently it exercises a positive molding force upon man, so that natural man may be the man who is molded by the external force of "nature".

We must not insist too much on this interpretation. 3

In the Preface de Narcisse there is a passage which would seem to invalidate this conclusion and which is of the more importance since it belongs to the same period as the first Discourse. Here Rousseau says that in Europe civilization (i.e. government, laws, customs) makes it necessary for men to be bad in order to get along. Here is an external molding force which is just the opposite of nature. Among savages, he continues, personal

1. Dernlere Reponse. V. 13. D. 190, note.

2. See for instance the opening chapter of the Confessions, where he speaks of nature as having broken the mould from which she made him.

3. Narcisse, ou I'Amant de Lui-meme, a drama written in 1730 when Rousseau was elghteen years old. Present in 1752, at which time the preface was written.

4. Preface de Narc1sse. V. 15 p. xxxi11, note $(\mathrm{g})$ to p. $x x x 11$ 
interest is just as strong as it is among civilized people, but it prompts a different sort of action. There is no question of property to divide them, and they are kept together by a love of society and by a need of common defense. Hence the great incentive to action is a desire for public esteem. It follows from this that the savage who commits an evil deed will not repeat it, and consequently there can be no habit of evil doing. Here again the molding force cannot be called nature, at least in the sense of universal order. It is rather the inner nature of the people. Perhaps, however, the significant thing about the passage is its recognition of the savage as the natural man, whether or not the natural man is necessarily a savage.

In the Essai sur I'Origine des Langues ${ }^{2}$ the savage is again described as a natural man, and two motives are added unto him. Self-defense is the great incentive to action among savages, but laziness is the great cause of inaction, and hence that which keeps him a savage. So far as I know Rousseau never again deells on man's natural inactivity, yet it is difficult to see how his theory of the state of nature is tenable without a sub-stratum of belief in the ultimate indolence of the human species. It may

1. Loc. c1t.

2. The essay is undated, but Vaughan says (Political Writings of J. J. Rousseau, I. p. 10 , note 2) that it may have preceded the second if not also the first Discourse. The text of the essay is given, Deuvres, V. 16, pp. $211-325$.

3. Oeuvres, V. 16 , p. 265 , note. 
be that Rousseau thought the proposition so simple as not to need explaining.

The Essay on the State of War contributes to man's natural endowment the qualities of peacefulness and timidity. It is ridiculous, says Rousseau, to maintain that man's natural condition is that of a war of each against all. Man is naturally peaceful and timid, and flees at the first sign of danger. There is nothing in the state of nature to make him warlike. It is only after he has known the society of another man that he determines to attack anyone, only after he has been a citizen that he becomes a soldier. Rousseau explains this extraordinary virtue by saying it is commanded by natural law, which is written on the hearts of men. This does not mean that there can be no fighting in the state of nature. There may be individual quarrels, and occasionally someone may get killed, but there can be neither continued strife nor continued ground for controversy. The idea seems to be that the unit in the state of nature is the individual, and he is so far 1solated that his relations with his fellows are too few to give rise to war. This is stated rather clearly a little farther on. Man, after, all, has no necessary connection with his fellows. He needs them less than he needs the fruits of

1. Vaughan, I, pp. 293-307. Vaughan places the essay as belonging to the same period as the second Discourse or perhaps a little earlier. I am inclined to regard it as earlier.

2. Vaughan, I, po 294. Again the emphasis on feeling rather than reason.

3. Vaughan, I, p. 294.

4. Vaughan, I, p. 297. 
the earth which are produced in sufficient quantity to feed him.

Another interesting point is that Rousseau belleves nature has flxed a definite limit to man's ablilty, beyond which he cannot go. It is again the idea of necessity curiously conceived, that looks out at us. Man has such and such qualities, such and such measurements. He may alter these things to such and such an extent only and then he must stop.

The Essay on the State of War is a curlous piece of writing, perhaps because it was never revised for publication. It is written with the avowed aim of disproving Hobbes' doctrine that war was the natural condition of man, but it shies off so speedily into a discussion of war in the (more or less) civil state that we must resort to indidental remarks for information on the natural man. It is quite evident from these incidental remarks that the natural man is again, and this time more definitely, the pre-savage creature.

With this in mind, we are somewhat prepared for the description of natural man which is given us in the second Discourse.

The second Discourse or Discourse on Inequality was written in 1753 for a prize offered by the Academy of Dijon on the question "What is the origin of inequality among men, and is

1. The full title is Discours sur I'Origine et les Fondements de I'Inegalite parmi les Hommes. 
1t authorized by natural law?" In answering the question Rousseau followed much the same scheme he had followed four jears earlier. In the state of nature, he says, men were equal. Departure from the state of nature has led to the inequality of their condition. But this time the departure from the state of nature came about through the origin of property.

The main argument of the Discourse is not new in Rousseau's thought and it is one he clings to for years until, in 1762, it makes its last appearance in the Social Contract. But the Discourse gives us our most definite and complete picture of the natural man. Indeed the whole first part of the Discourse is devoted to just such a picture, painted with such vividness that we must accopt it gratefully and never hope to find lts like again.

The man so drawn for us is little more than an animal, "weaker than some, and less agile than others, but taking him all round, the most advantageously organized of any". He satisfies his hunger at the first oak tree, slakes his thirst at the first brook, sleeps under the tree which fed him, and so has all his wants supplied. But he is a splendidly healthy animal, for all the weaklings die and only the strong survive. His daily struggle

1. Everyman ed. Soclal Contract and Discourses translated by G. D. H. Cole, p. 155 .

2. "Origin of Inequality" Everyman ed. Soc. Cont. and Disc. p. 177 3. Loc. c1t. 4. p. 178 
with wild animals makes him both strong and clever, and both the strength and the cleverness tend to increase with use. This man is a self-reliant creature, living almost completely alone. He has no flxed abode, and consequently no family ties, no language, no means of communication. Any intercourse with his fellows is due to chance and is of a momentary and casual nature. The nearest approach to any permanent social relation is the relation between mother and child. Even this, however, is of short duration, and $\frac{11 k e l y}{2}$ to be terminated the moment they no longer need one another.

So much for the physical side of our man. Living under these conditions he is quite happy. Illness is foreign to him. His needs are purely physical and of such a nature that they can be taken care of by instinct and without thought. Indeed thought is contrary to his nature. When he begins to think, he is a depraved animal. But if our man has not thought in our sense of the word he has ideas and instincts to govern his conduct. Ideas and instincts are the volce of nature speaking in man. Among the instincts we may discover those pertaining to his physical wellbeing, that is the desire for "food, a female, and sleep" and the

$$
\begin{array}{ll}
\text { 1. p. } 179 \\
\text { 2. p. } 189 \\
\text { 3. ค. } 185 \\
\text { 4. p. } 181 \\
\text { 5. :p. } 184
\end{array}
$$


fear of pain and hunger. Any harshness or cruelty that might arlse from the instinct of self-preservation will be tempered by man's natural compassion, which is perhaps his only natural virtue. He is subject to fewer passions than the civilized man, and is negatively, at least, virtuous.

This natural man seems to be the same pre-savage creature who figured in the First Discourge. But upon examination it will be seen that this is not true. The same man, or nearly the same man is being described, but now he is not the man who was, but the man who should have been. Rousseau has ceased to deal with the actual and begun to consider the ideal. It is important he thinks to know man, but it is very difficult to know him in his original condition, without the changes that have been made by time. In order to get some idea of this original condition, Rousseau proposes by a process of abstraction to distinguish between what is original and what is artificial in his nature, and to describe him in that state which "no longer exists, perhaps never did exist and probably never will exist". Man is no longer the savage. He has become instead an Ideal and typical individual. Thus, while his qualities are the same as those of the savage, he himself is not necessarily savage. In

$$
\begin{aligned}
& \text { 1. p. } 186 \\
& \text { 2. p. } 197 \\
& \text { 3. p. } 168 \\
& \text { 4. p. } 169 \text {. The statement is repeated on p. } 175 \text {. }
\end{aligned}
$$


so far as civilized man might conform to his type he could be civilized.

The Discours sur I'Inegalite dis not win a prize and was some two years in getting published. This may account for the fact that there was not as much excitement ofer it as there had been over the First Discourse. At any rate the only thing Rousseau thought worth answering was written by one Philopolis. 14. Philopolis saw an apparent absurdity in a civilization's arising naturally among men in a condition where civilization not only was not natural, but did not exist. The gentleman claimed that civilization is the work of man and is therefore natural. Rousseau admitted the proposition, with the curlous observation that in his scheme civilization was the old age of man. As a corollary to this he states again his belief that man can only progress so far, and for that reason it is well to slow up development. The Lettre a M. Philopolis ${ }^{3}$ is, save for these two points, of no interest to us.

From the writing of this letter to the publication of Emile and the Social Contract in 1762, Rousseau has nothing of

1. A Nom de plume. His name was Charles Bonald and he was a naturalist.

2. See above. p. 18

3. V. VII, pp. 241-255 (ed. of 1793) 
interest for us. The Soclal Contract is not concerned with the state of nature so much as with the establishment of societies, but it is based on the assumption of a state of nature prior to civilization. Had the idea been developed it probably would have followed the same line as the Discourses. But it was not developed.

The most interesting and the most important development of. the conception of natural man occurs in the Emile. Emile 18 a treatise on education, based on the assumption that there is a natural man and that education ought to keep him natural. Perhaps the most fundamental attribute of the natural man here is $\mathrm{h} 1 \mathrm{~s}$ original and natural goodness. This means that education will not have to struggle against his nature, but may proceed to keep him as natural as possible, to keep him from vice rather than to teach him virtue.

A certain amount of natural ability is assumed in the child and a certain natural development. The stages may be described more properly in the second part of this paper. Only a few of the major points must be noted here. The first and most important is the natural goodness of man, the second, that the natural man may exist in a civilized society, the third, that he 1s capable of mental development, and last that he has some

1. In 1756 there was a letter to Voltaire, more controversial than interesting, and in 1760 the Nouvelle Heloise which will be discussed in $\mathrm{Ch}$. II. 
Innate power to reason. In all but the first point this description differs entirely from the others. Yet I think it is safe to say that by 1762 the natural man Rousseau belleved in was not a savage, but a civilized creature, a man that nature had made after her Elghteenth Century pattern, and unspolled by soc1ety.

So far in our study we have found three stages in the development of natural man, all more or less indistinct, and each growing out of the last.. The first idea presented was that of the savage or pre-savage. By the time of the Second D1scuarse the savage had become a type, a symbol of an ldeal state that never had existed. And by the time Emile was written this abe straction had given way to the bellef that natural man existed and (mercifully) persisted within the civilized man, not as his enemy but as a part, and a most important part, of him. The idea had at last assumed such form that some practical use might be made of it.

To be sure Rousseau had made use of his theory even before he had fully developed 1t, but the utmost lenlency will not allow us to describe it as a practical use. Rousseau fancled himself as a natural man, and tried to live up to his specifications. He always had a passlonate love for nature, for the out-of-doors, and this showed itgelf in several ways. He loved to live in the country, was happy nowhere else, and in order to gratify his desire, forsook certain prosperity to 
witharaw to a little country house of Madame d'Epinay. In his youth he several times went vagabonding, and when he was an old man, preparing to die, his dearest amusement was to take long walks by himself, herborizing, as he called it, and enjoying his own thoughts. Herborizing was one of his greatest amusements, and led to the writing of several pieces on botany.

Rousseau endeavored to make the physical conditions of his life as nearly natural as possible. He could not quite accomplish his purpose, for his disease demanded expert attention. But aside from this one exception, he lived as nearly natural a life as civilization would.permit. He did not marry his mistress and he neither legitimatized nor cared for his children. Faced with the unfortunate necessity of wearing clothes, he wore the simplest and plainest obtainable. His house was very simple and his tastes of the plainest. Like the herome of the Nouvelle Heloise, he supplied his table with the simplest of foods, relying on appetite and good company to make it palatable. The simplicity of his life had, at least in his own description of it, the arcadian quality which Rousseau himself made traditional in romantic literature. It was emphatically, blatantly, "poor but honest", but it fortunately has no suggestion of Horatio Alger.

1. The famous Hermitage, Rousseau forsook what he believed would have become fame and fortune from the production of his operas. And he certainly refused a pension from the king. Conf. I

2. Reveries, passim.

3. Herborizer (sic) Reveries 
One reason for this simplicity is of course Rousseau's revolt against the civilization of his own day with its falsity and its abundance of ornamentation. In another age Rousseau would not have had so much incentive to admire and emulate the lowly peasant.

Although his chances of physical approximation to the state of nature were somewhat damaged by the necessity of living in the Eighteenth Century, Rousseau still possessed the moral qualities of the natural man. He had a greater abllity to reason than he at first allowed his natural man, but he was so completely governed by his emotions that in this respect at least he practised what he preached. The first thing which occurs to us when we read the autoblographical work is that the author had an appalling amount of ego. If we are asked, however, for their outstanding characteristic, we will probably say they are emotional. The very style is oratorical, and therefore emotional. The works examine into the life and thoughts of the author, and what they reveal is that he lives according to the volce which speaks within him. He is expressing his nature.

Because Rousseau lived as he did he ran a great chance of being classed as harmlessly insane. But he justified himself in his writings. So he became a great philosopher. People would never have followed Rousseau's example if he had not written about 1t. It is just barely possible that the writing would not have been effective without the living example. Certain it 1s, however, that the two together were most effective. The Nine- 
teenth Century would have happened without Rousseau, but it was Rousseau that made it romantic. 
A person who showed Rousseau's interest in the natural man might be expected to have some ideas about the natural woman. Rousseau was more or less interested in women all his life, and sald so in no uncertain terms. But he seems to have considered them for a long time as unworthy of philosophy. While he never gave expression to it, he seems almost to have felt something like contempt for all women. On one occasion he remarked that the most charming thing in nature was a pleasant and virtuous woman, but he was a little skeptical about her existence. Skeptical he may well have been for of all the women he knew, many were charning, only a few were virtuous, and none combined both qualities.

When Rousseau began to think about the natural man he was forced to take account also of the natural woman. She received scant attention at first, and seems to have been first mentioned in the Discourse on Inequality. Natural woman was to Rousseau only the female of the species Natural Man. This was almost necessary in dealing with an undifferentiated society, or with an abstract, ,type man. The type man was typical of the species, and as the male-ness or female-ness of the creature was not in question, the female needed no discussion. Under the circumstances it is rather surprising that she got any, but there was some incidental discussion in the Second Discourse. By 1762 the matter had become important enough for a whole book, and the

1. Lettre a M. d'Alembert, V. 11, p. 270 
result was the Nouvelle Heloise. In Emile the natural woman receives considerable attention, in Emile and Sophie she appears again, and she has managed to occupy a fair portion of the Letter to d'Alembert. In all these four the natural woman is something besides a mere female. The more differentiated society which is under consideration has brought out, perhaps, the differences between men and women other than those of sex.

As has been sald, the natural woman as she appears in the Second Discourse is simply the female of the species. We may assume, indeed we must assume, in the absence of specific statement, that she has the same qualities as the natural man. She is physicallỳ strong, a splendid animal, living the wild, forest life that is described for the man. Mentaily she is as dull, stupid, and ignorant as he 1s, and she has the same moral and emotional qualities as he has. Indeed, Rousseau glves us our only information regarding her character when he talksoof the functions relating to sex-as if that were the only respect in which she merited consideration. We learn, for instance, that in a state of nature love is purely physical, that in the absence of any moral phase one woman is as good as another, and that the union of the sexes is casual and almost unconsclous. The woman suckles her children at first for her own sake, and afterwards,

1. Everyman--Social Contract and D1scourses, p. 201

2. Loc. cit.

3. Op. cit. $--p \cdot 189$ 
when hablt has made them dear, for theirs; but they do not remain with her when they no longer need her. Even when her children are with her a woman is almost as much alone as a man, for she has no way of communicating with them, and sight is her only means of recognizing them.

There is a curlous passage regarding the nature of woman right in the midst of these other observations. "It is easy to see", says Rousseau, "that the moral part of love is a factitious feeling, born of social usage, and enhanced by the women with much care and cleverness, to establish their empire, and put in power the sex which ought to obey." ${ }^{2}$ The observations concerning the moral aspect of love has been made elsewhere. But there are two conclusions to be drawn, from the statement-first that women ought, 1deally, to obey; and second, that they have been sufficiently clever to command. This passage is exceedingly curious in the light of a passage in the dedication of this very Discourse. The passage, coming after a long eulogy on the Republic of Geneva, reads as follows:

"I must not forget that preclous half of the Republic, which makes the happlness of the other; and whose sweetness and prudence preserve its tranquility and virtue. Amiable and virtuous daughters of Geneva, it will be always the lot of your sex to govern ours. Happy are we as long as your chaste influence solely exercised within the limits of conjugal union, is exerted 3 only for the glory of the state and the happiness of the public."

1. Everyman--Social Contract and Discourses, p. 189

2. p. 201

3. p. 166. Italies mine. 
Here Rousseau speaks as though the women of Genera actually were amiable and virtuous, and as if it were well for them to govern (within limits). How are we to take this in conjunction with the passage in the body of the Discourse? I think we must take it cum grava sal1s. The observation in the text is a by-the-way remark, wholly in keeping with the rest of the essay and especially with the other remarks on women. Here he simply thinks it expedient to flatter the women of Geneva, and he does so.

our suspicion as to the sincerity of the remarks in the dedication is increased when we find the first point restated in the Iettre a M. d'Alembert. This letter, which devotes a surprising amount of space to women, was occasioned by d'Alembert's article "Geneva" in the Encyclopedia. The upshot of the discussion is that nature has designed women for motherhood and for the duties of the home and that outside of these things she can have no interests and no rights. "Love", says Rousseau, "1s the kingdom of women. It is they who necessarily give it its law; for, according to the order of nature, resistance belongs to them, and men cannot conquer that resistance except at the expense of the1r Iiberty." And again, he thinks that woman has such a softening effect on man, that for his good he should keep away from her.

1. Oeuvres V. 11, p. 269

2. Oeuvres V. 11, pp. 376-377 
Evidently Rousseau was afraid of the natural woman and her natural instincts.

In the Nouvelle Heloise woman appears as wife and mother, but also to some extent as a person. The primary interest is st1ll sex, but Julie has some character of her own. Julle is the daughter of a proud nobleman. She loves her tutor and wishes to marry him,bbut her father will not dream of permitting her to wed a mere teacher. What could a natural woman do in such circumstances? As Morley so delicately puts 1t, she deliberately and In very despertion "lost the self-control of virtue" and flung herself "Into the pit that lies so ready to our feet". Bound to her lover by passion, but helpless before the opposition of her father, she hoped by her act to force his consent to her marriage. But no sooner was it done than she was overcome with remorse. At last Julle yielded to her father, whom she loved dearly, and married the man he had selected for her.

So far our natural woman is not very different from her primitive ancestor. Conditions have changed. The convention of marriage must be reckoned with. But the woman herself is the same woman, and the problem is still the sex problem. Only in one particular does Julie give us a hint of the way in which this unwelcome marriage is to affect her nature. She has sacrificed her personal preference to her duty. But the rest of the story

1. Morley: Rousseau and His Era, II, p. 25 
deals in this one element of duty which has so far not been mentioned in connection with natural woman. Once Julie is married, the guiding principle of her life becomes immediately, and as if by magic, not love but duty. In duty, rather than in love, she assumes and fulfils her obligations as a wife. She puts by the old love so completely that when her former lover makes her a. Iong visit she can see him without loss of virtue, or even of sleep. She loves her children dearly and cares for them tenderly, as is natural, and she entertains a deep respect for their father. Her natural sympathy leads to a deep interest in and sympathy for people, so that she becomes the friend of peasants, servants, and beggars. And she is religious to the point of pietism.

Julle's story is told with a view to depicting natural reactions, and Julie's conduct is conceived of as being all that is natural. We may see then, that aside from her passionate feeling for her lover and her tender regard for her chlldren, the natural woman has several other emotions. The first and greatest of these is duty, but following close behind duty are the allied emotions of sympathy and religion. Rousseau had from the first emphasized the importance of sex in the natural woman. But here we have for the first time a love of one person, or what Rousseau would describe as moral love. Sympathy was recognized from the as belonging to the natural character of the race and hence to women, but duty and religion become important to the natural

1. Some indication that this was Rousseau's deliberate intention is given in the preface to the Nouvelle Heloise. passim. 
woman here for the first time. And whereas marriage would have been considered unnatural for the primitive woman, here it is not considered as having a direct part in her nature. It is simply a condition under which that nature develops. The same may be sald of the whole of civilizations In other words, Rousseau is considering woman not in her primitive condition but in her "constitution" or her inner nature.

The same may be sald of Sophle, the natural woman of the Emile. Sophie is an Eighteenth Century woman just as Julie 1s, and just as Emile is an Eighteenth Century man. Sophle unfortunately reverses the experience of Julle, but in this she is perhaps more in accord with her own time. For, like the good Eighteenth Century girl she was, Sophie indulged in all her duty, obedience, and religion during girlhood, deviating from the type only by loving the man her parents selected for her. She had all her adventure at the time when Julle, was occupled with being a respectful wife and devoted mother.

Julle seems to have been portrayed for us as a natural woman. Sophle, however, was undoubtedly drawn as the counterpart of natural man. Julie's intelligence was not mentioned, but the narrative revealed it incidentally, in spite of Rousseau. But Sophle is expressly denled intelligence. Her sole guide, the key to her whole nature is duty; even her religion and her marriage are dictated by her duty to her parents. But duty itself is not strong enough to keep her falthful to her husband, although it 
does make her a devoted mother. Sophle's lapse from virtue is as difficult to explain logically in a woman who has been entirely governed by duty, as Julle's suddenly developed sense of duty is difficult to explain in one who has given herself over to love.

A recapitulation of the elements which remain constant in these various philosophles of the nature of woman will give us a truer insight into Rousseau's idea than any one undivided portrait could give us. Natural woman, we find, is always subordinate to natural man. She is important only for her sex, to gratify the passion of the male and to perpetuate the race. But by the accident of being human she possesses also certain other qualities, such as love, duty, sympathy, etc., all of them emotional--for intelligence is reserved to the lordly male. These emotional qualities are evidently considered as contingent upon sex, for the male does not have all of them, and they seem to be the qualities which render woman, pleasing and give her her distinctive character. Woman, whether he called her natural or unnatural, obtained her chief merit in Rousseau's eyes from the lact that she was necessary to man.

It would be interesting to find a woman in Rousseau's Ilfe who fitted his description of the natural woman, or who bore the same relation to her as Rousseau himself bore to the natural man. In our search for such a woman, we will soon perceive that the "amiable and virtuous" one is not to be found. The nearest 
approach to her is perhaps Therese Levasseur who was for so many years the mistress of Rousseau. Therese was far more nearly the "natural woman" of Rousseau's philosophy and the counterpart of Rousseau himself as the "natural man" than, for instance, Madame d'Hudetot, who is supposed to have been the original of Julie. In this connection we may note that madame d'Hudetot in no way resembled Julie, and the only connection between them is Rousseau's admission that she was constantly in his thoughts while he was writing that novel.

Madame d'Hudetot was an Eighteenth Century type of woman with all the Eighteenth Century convention and lack of convention. So were most of the other women of whom Rousseau tells us. The only woman who was strikingly different was Therese Levasseur. Therese was a servant girl. This perhaps accounts for the absence of the Eighteenth Century mind. It was a luxury not for servants. It certainly accounts for Rousseau's feeling for her, for he too was lower class. Therese fulfilled Rousseau's idea of the most charming thing in nature. She was unquestionable amiable, and in Rousseau's eyes she was virtuous. We of the Twentieth Century would deny that virtueeon the technicality that she was Rousseau's mistress, but Rousseau did not have our prejudices. Therese remained faithful to him (remarkable feat) as long as he lived, bore his children, sacrificed them for his sake to a foundling asylum, cared for him and made him as happy as a man of his temperament could be made. She thus fulfilled the most important 
requirements of the "natural woman". She made herself necessary ta Rousseau and followed what was obviously her duty in taking care of that necessity. Indeed duty must have been an important motivator of Therese's action. Rousseau was not pleasant to live with, but she remained with him long after he had become a burden to her, and long after she had become attracted to another nan.

As for Therese's mental qualities, they were those of the primitive woman. Rousseau sald of her, "Her mind is as nature formed 1t; it is not susceptible of cultivation". Yet that mind was sound and intelligent. It was simply that Therese had been, like the primitive woman, untouched by the civilizing process. Rousseau was a "natural man" at least partly because of his philosopht. Therese was more truly a "natural woman" because she did not know she was . She was completely artless and quite as nature had made her. She had, therefore, so much the more attraction for Rousseau.

1. Confession, Bk. VII 
Much of Rousgeau's work is to be explained by his life, for his thinking was introspective, centered around himself and his feeling, rather than proceeding from clear logic. He frequentlyhheld two views on a subject, and on education, for instance, he held a great many, but he was never insincere. H1s work carries the conviction that whatever he may say to the contrary elsewhere, he belleves what he writes while writing 1 . But to only one ldea does he hold throughout all his work, and that is the basic idea of his philosophy, that of a return to a state of nature. It is not difficult to understand why he had such an 1dea when we understand how natural he was himself, how absolutely frank, simple, and unafraid, and to what a remarkable extent his vagabond $11 \mathrm{fe}$ and his impressionable spirit were influenced by nature. Nor is it difficult to understand how such a man, influenced by the events of his own life, should keep his interest in social problems, and in the peasant class, or how, looking back over his own unhappy jouth and troubled maturity, he should think out a system of education which would allow the youth to develop naturally and happlly.

And it was for such a system that Rousseau planned in all his various attempts at an educational system. The earliest scheme he outlines is that set forth in the Projet pour I'Education de M. de Sainte-Marie, written apparently in 1741; for Mably.

1. Bonnot de Mably, elder brother of the philosopher and of Condorcet. 
M. de Sainte-Marle was the older of Mably's sons, and was imaginative, high spirited, and mischlevous, so that he kept his tutor 2 busy. Rousseau proposed to his father to give him first of all such moral instruction as was suitable to his years, and such knowledge of his fellow human beings as he was capable of understanding, always in a form as simple and as far removed as possible from that of formal instruction. Then he wished to keep him away from his brothers and sisters a part of the time, so that he might study. To do this Rouggeau proposed to create a counter-interest by giving him a room of his own and placing in it simple things, magnets, prisms, etc., in order to interest him in his studies. As for his actual studies, he was to learn a great deal of natural hlstory, modern and partịcularly French history, Latin, and, because he was destined for the army, some mathematicsaand geography. He was to be taught to read Latin fluently, but not towwite it, because that was something he would never need, and it was an an exercise so dreadful that it would counteract every effort to make his like his studies. For the same reason he was not to be taught logic, rhetoric, or philosophy until he was quite grown, and then he was to read the Port Rojalist logic merely to acquire style.

The system is not outlined completely, as it is in the Emile. It is simply designed for immediate utility. In this connection it is important to note that the scheme was intended

1. Conf. II, Book IX. 
for actual use with a real pupil whom Rousseau had taught for some time, and with whose vagarles he was thoroughly acquadnted. There is apparently no intertion to change or eliminate any peculiarities. The plan is to take advantages of the natural interest and emotions of the child in order to teach him. A project for giving him magnets, prisms, etc., is simply designed to attract the attention and to appeal to the boy's instincts. He was not expected to learn much from having them, but he was expected to become interested and to wish to study.n The fact that the Projet pour I'Education de M. de Ste.-Marie places so much emphasis on the content of education should not obscure the fact that it prescribes new methods. There is even some naturalistic material among the things SterMarie was supposed to study. Twenty years after he wrote this little plan Rousseau was to include natural history and geography in Emiles course of study.

The next mention made of education is that in the Discours sur les Arts et Sciences (1749). Here he rails against the existing formal type of education, and advises giving children plenty of exerclse and teaching them "what they must do when they are men, and not what they must forget". In the more famous and less successful D1scours sur I'origine et les Fondements de I'Inegalite parmi les Hommes, (1753), he says that education has contributed to the growth of inequality.

1. Oeuvres, $13 ;$ p. 77. 
In the Nouvelle Helolse there are two passages on education. The first passage occurs in one of the early letters to Julle from her tutor. He marks out a course of reading for her, limiting it to books of "taste and morals", and eliminating foreign languages and, with a few exceptions, all poetry and sentimental books, because they tend to welken the moral fibre. This is just the sort of thing we would expect since we have seen the emphais which Rousseau placed on the moral part of man's nature. Julie is also advised to stop mathematics, physics, and all history but ancient history and that of her own country. The seeond passage occurs. In the latter part of the book. Julle has asked Saint-Preux to undertake the education of her two youngest chlldren, both boys, and she outlines to him the plan on which she has proceeded and on which she wishes him to proceed. Children, she says, are children, not little men. They cannot reason, and therefore they should not be reasoned with. As far as possible they should be left to develop naturally and alone, but under the secret tender supervision of the parental eye. They are not to be stuffed with useless knowledge; the most important thing in the early years is to make them fit to be pupils. They are not to be taught the catechlsm for fear of injury to their religion, but they may be allowed to absorb a religious attitude by hearing their mother say her prayers. All this is the scheme of education in the

1. Part I, letter 12.

2. Part V, letter 3 . 
early years when they are under their mother's care. When they are old enough to begin their real studies, they are to be turned over to their father or to a tutor. Julie knows her place and intends to keep it.

II

The Nouvelle Helolse was written just before the Emile, at a time when the author was concerned with the educational problem, and the ldeas that it contains are the germs of those that are developed more fully in the Emile. Like the Nouvelle Heloise, the Emile is a novel in form, but much more atrocious as such. It is very unevenly written, sometimes being narration, sometimes instruction, sometimes exhortation, but in its main outlines it is the account of the ideal education of an ideal boy whose tutor Rousseau Imagines himself to be. The book is divided into five parts, of which the first four correspond to four perlods in Emile's life, infancy, chlldhood, boyhood, and youth. The fifth part is devoted to the education of the girl who is destined to become Emile's wife.

Emile was written with the avoted purpose of providing a scheme of education which should be in accordance with the natural development of the child. The great trouble in existing educational systems, Rousseau thought, was that they took no account of the nature of the child. "We know nothing of childhood; and with our mistaken notions the further we advance the further we go astrgy. The wisest writers devote themselves to

1. Because the first two books are so nearly inseparable they will be discussed as a unit. 
what a man ought to know, without asking what a child is capable of learning. They are always looking for the man in the child, without considering what he is before he becomes a man. It is to this study that I have chiefly devoted myself ..." And again he described the "systematic portion" of Emile as "nothing more than the course of nature". The plan, then, is to determine the nature of the child, and make the course of education follow that of nature, for Rousseau thought that everything except life itrelf is the gift of education. Education, then, is conceived of in the wider sense in which 1 t has since been made fammliar to us by psychologists and professed disciples of Rousseau. Education comes from nature, from men, and from things, that of nature being the "Inner growth of the organs"; that of man, the use we make of this growth; and that of things, the experience we gain from our surroundings.

Of these three, only that of nature is utterly beyond our control. Therefore we ought to make the other two forms of education follow that of nature in order to get the most harmonlous development of the individual. This idea leads directiy to that of "negative education", the objective of which is to leave the mind undisturbed until it is capable of receiving an education. Rousseau considered that such a system would keep the

1. Everyman ed.--p. 1, Author's Preface.

2. Ibid. $--p, 2$

3. Ibid.--p. 66

4. Ib!̣d.--p. 6 
child free from viee, and that was a positive gain, for he is naturally good.

This negative education, which is to occupy the first twelve years of the child's life, is by no means as simple as It sounds, especially for the tutor. On its negative side, so to speak, it consists largely in the absence of formal instruction. But education, as distinct from instruction, is considered as beginning at birth. For this reason almost the whole first book of Emile is given over to discussion of very young children. Mothers are exhorted to care for their own children. and voluminous instruction is given them for doing it. Rousseau even goes so far as to say that ideally and where control is possible, the child should be born in a temperate climate, and in the country rather than the city, and to prescribe a vegetable diet for the woman who is nursing her child.

The child itself should be clean and well fed, and should be kept free from confining clothing in order that he may grow strálght and strong. His needs should be attended to promptly, but too much attention should not be given to his caprices or he will become willful and tyrannical. On the other hand his wishes should never be refused arbitrarily; refusal

1. Emile--p. 19

2. Ibid.--p. 26

3. Ibid.--p. 26

4. \$bid.--p. 69 
should come from nature. He cannot rebel agalnst necessity. All these provisions are in the interest of keeping the child in his place. Nature has made him weak; it is not for'his teachers to fool him with the pretense that he is strong. Nature has decreed that he must obey; he must not be allowed to command. Physically he should becomeilnured to pain and hardship, and should have a great deal of exercise, so that he may grow strong and self sufficlent. Morally, the child should have little instruction. He cannot understand 1t, for he is completely unmoral. The only moral lesson he may properly be taught is the greatest one of all, "Never hurt anybody" . He may acquire certain virtues by imitation, but if he is taught, he will simply learn to prate about them. Even the moral education of fables is beyond his grasp. Though formal education is forbidden in these early years, there is a great deal which Emmle must learn without books. He must learn such things now that he will be ready for study when the time come. The first thing, then, is to train the senses, which are the first faculties to mature. To this end Emile is assisted in making an elaborate series of very simple sense judgments. He is taught to estimate size, distance, speed, weight, etc., and to verify as $\underset{4}{\operatorname{far}}$ as possible, every impression of one sense by that of another.

1. Emile--p. 69

2. Ibid. - -p. 68

3. Ibid.--p. 77

4. Ibid. -- p. 97 
Formal geometry and drawing are not suitable to a child, but these things he may be taught informally and without books. He should learn to draw from nature. Th1s w1ll amuse him at the same time that it helps him to establish the true perspective relation between objects. He should not learn the theory of geometry at all. This is beyond him. But it will interest and help him to learn accurate construction and to discover for himself the nature of an angle and a circle. Reading he will perhaps learn by accident or desire. It should not be taught him. Languages he should not learn since he cannot compare ideas, but merely memorizes words. History is meaningless to him, and geography gives him no idea of the earth, of which it professes to teach, but only of maps and globes.

Formal education should begin when the childils about 3

twelve years old. Hitherto he has been a little animal absorbed in supplying his physical needs. Now for the first time his strength is in excess of his needs, and he has some to spare for studies. But there are an infinite number of things in the world to learn, and Emile has only a short time to devote tollearning them. Hence he must be taught carefully selected subjects, and even these should be taught not so much that he may know them thoroughly as that he may have a desire to learn of them and the

1. Em1le--pp. $108 \mathrm{ff}$.

2. Ibid.--pp. 77-82

3. Imile--p. 127. The following two paragraphs are taken from Book III, Emmle--pp. 127-171 
Formal geometry and drawing are not suitable to a child, but these things he may be taught informally and without books. He should learn to draw from nature. Th1s w1ll amuse him at the same time that it helps him to establish the true perspective relation between objects. He should not learn the theory of geometry at all. This is beyond him. But it will interest and help him to learn accurate construction and to discover for himself the nature of an angle and a circle. Reading he will perhaps learn by accident or desire. It should not be taught him. Languages he should not learn since he cannot compare ideas, but merely memorizes words. History is meaningless to him, and geography gives him no idea of the earth, of which it professes to teach, but only of maps and globes.

Formal education should begin when the childils about 3

twelve years old. Hitherto he has been a little animal absorbed in supplying his physical needs. Now for the first time his strength is in excess of his needs, and he has some to spare for studies. But there are an infinite number of things in the world to learn, and Emile has only a short time to devote tollearning them. Hence he must be taught carefully selected subjects, and even these should be taught not so much that he may know them thoroughly as that he may have a desire to learn of them and the

1. Em1le--pp. $108 \mathrm{ff}$.

2. Ibid.--pp. 77-82

3. Imile--p. 127. The following two paragraphs are taken from Book III, Emmle--pp. 127-171 
and the means to obtain any special knowledge he may desire. At this age sciences may be taught, but they should be taught without instruments. Let the child make his own instruments. If they are crude and simple, this defect will be more than counterbalanced by the experience and the first-hand knowledge acquired in making them. Let all the experiments be connected together by some chain of reasoning so that they follow an orderly sequence in the mind and may be recalled at need, but do not go too far into purely theoretical science. Utility is asgood standard for knowledge, provided the child recognizes the utility. If he does not recognize utility he must be shown, not told. If it is at all possible, such studies as are given to the child should be so correlated as to make them easy and interesting.

The child should not be troubled with any soclal relations which he cannot understand. He should observe everything around him and exchange what he has for what he needs and does not have. Thus he will be able to understand social relations before he is a member of society. He should be fitted to preserve his own life, not to fill a position. of all the trades by which a man may earn his bread, manual labor is the nearest to nature. Agriculture is the oldest and most honest industry, but in case Emile should lose his father's lands, he should have a trade, and 1t should be one at which his head works not quite so hard as his hands. The trade should be one Emile likes, and it should be sufficiently difficult to prevent his getting the ldea that life is a dream, but it should not be dangerous. Moreover, Emilesshould not get the ldea of working 
for money. His work should never be judged by any standard but that of a master.

A child that is properly educated will know nothing of of emotion for a long time. Children do not feel, they simply are. Those children who have learned to prate of feelings know nothing of them. They have merely learned a lot of words, but the habit of expressing that which they do not feel will help to harden them against real emotion. Only when the child has suffered will he be able to sympathize with the suffering and the joy of others. The first and most natural feeling is self-love. It is the root of self-preservation and the cause of love for others. It leads us to love first those who serve us, then gradually all mankind. This is present in the child. All other moral and aesthetic qualities must be added uhto him. Youth, not childhood, is the proper time for moral instruction. Fables, which Rousseau had thought improper for the teaching of children, are prescribed for the youth.

It is not wise to be too fastidious in speaking with children or to go out of one's way to avold calling a spade a spade. Modesty is natural to man, but it is not natural to children, for it only comes with a knowledge of evil and children without such knowledgecannot have the feeling it brings. There is no satisfactory way of preserving the child's innocence except by surrounding him with those who respect and love him. The child who is brought up in accordance with his age knows no 
attachment but that of habit, and suffers no passions at all. When he is old enough to have passions, then let them develop, being careful only to gulde them properly.

Youth should not be taught speculative matter, but things that fit it for life in society. Man must be studied in society and society in the individual. Man must be seen as he really is, and for this history is the most useful study. Man in society is seen as he wishes to appear. Man in the perspective of history is seen as he is. Even his own opinionoof himself is useful here, for it adds so much to the sum total of the knowledge we have of him. The only danger about history is thatil sets forth the evil and conceals the good, so that youth is likely to be deceived by $1 t$.

Children should be taught nothing of religion. They cannot understand it, and when they have to accept it without understanding, they will in all likelihood never understand it, and they will have learned to accept other things in thessame way. By the period of youth the pupil will have learned to reason, and reason will lead him to a natural religion, provided always that no concessions are made to authority or to prejudice.

The outlines and foundation of this natural religion or delsm are set forth in Book IV of the Emile, in the famous Profession de fol du Vicaire Savoyard. The Savoyard Vicar is a

1. pp. $228-278$. 
fictitious character used as the mouthpiece of Rousseau's theology. Motion, says the Vicar, obligingly speaking for Rousseau, can only originate in the will. Hence the universe is moved by will, but the laws of the universe show intelligence. The intelligent Being who moves the universe, then, is God. But we can know God only in his works, not in his essence. Man can governall creatures; hence they must be made for him. All nature is harmonious but man, and he has two natures, a passionate, sensual nature, and a higher, nobler nature. God has given him the will to choose between them and the power to follow his choice. Hence It is useless to pray to God, for he has already given you all that you need. But it is good to worship him and to perform your moral duties. The Vicar believed that hell existed in the hearts of the wicked. This, then, is the religion that Emile was expected to arrive at when he reached years of disctetion.

A youth who has not been given a great deal of pedantic instruction in childhood will probably have an appetite for study. He should not be allowed to indulge this toormuch, buthe should have a great deal of bodily exercise. Hunting is a good sport for him to indulge in if he can do so without becoming cruel, for it is a sport that will interest him to the exclusion of all else, and will occupy both mind and body.

In conclusion, a youth should not be kept too much alone. He must go among people at some time, and keeping him alone is a good way to make him awkward. Rousseau indulges in the novel plan of safeguarding Emile from the wiles of the wicked world by putting 
into his mind the image of his ideal sweetheart before letting him go among people. By starting him in quest of such a woman and taking care that he does not find her too soon, the tutor hopes to keep him free from unworthy women and prevent a tooeearly marriage. So, at the end of the fourth book of Emile, we have the hero and his tutor setting out to get the young man thoroughly tired of artificial society, and to find the ideal woman to be the wife of this ideal young man.

Sophy, as Rousseau names his conception of the ideal - woman, is by no means so fortunate as Emile, for Rousseau leaves Emile free, but Sophy he condemns to be simply the dutiful daughter of her parents and later the adoring handmaidoof her husband. Apparently he could imagine nothing better for womanhood, for he has Sophy educated for this purpose from her earliest youth. Women he conceives as inferior in. intellect but superior in wit. hence Sophy receives only such education as will make her an obedient and attractive wife, enable her to wind her husband around her little finger, and keep his house for him. Sophy, like Emile, is educated by a Great Principle. Her education is designed to follow what is natural for a woman just as Emile's is designed to follow what is natural for a man. Her natural vanity is made the means of teaching her to sew and to design. Her desire to please serves as an excuse to teach her to play and sing simple songs. She barely knows how to read, and she knows only enough arithmetic to enable her to keep her household accounts. But she has learned to keep house, althoughshe is so 
fastidious that she would much rather let everything be ruined than soil her hands. Any woman can see what kind of a housekeeper Sophy would have made. Besides these other virtues, this paragon of all the virtues that pertain to woman has learned to obey her mother unquestioningly and to expect to render the same obedience to her husband when she is so fortunate as to have one, and to expect that she must accept her husband's religion. One can fancy that from a masculine point of view these would be useful traits in a wife. Rare indeed is the man who asks for wife anything less than "a perfect woman, nobly planned, to warm, to comfort", and to be commanded. Rousseau, and therefore Emile, was in this respect normal. This, then, is the kind of a woman that the crafty Rousseau arranges for Emile to meet when he judges the time to be ripe. The clever tutor has taken his pupil tramping to show him man as he is, and through this, to give him a practical knowledge of government and soclety. Now he manages an accidental meeting between Sophy and Emile, in which each recognizes the other as the long-sought ideal and loses no time in falling desperately in love. Follows a long and ardent courtship on Emile's part, which his marvelous tutor uses to teach him new virtues. Sbphy, during this courtship, uses all the oldfashioned feminine wiles for which Rousseau has been careful to have her educated. When they have finally managed to get themselves engaged, the tutor Immediately drags Emile away in order to teach him self-control. Being a thoroughly wise man (in his own eyes), he takes the unusual course of introducing this idea 
to his pupil by asking what he would do if some one were to tell him that Sophy was dead. When the hero has recovered from this shock, he and his tutor start out on new travels, with which they occupy themselves for about two years. At the end of this time he and Sophy are reunited, married, and apparently started on the road to perfect happiness. The tutor has been successful in his work and now it is finished, or nearly so, for in the last chapter we have the hero declaring his intention of educating his child as he himself was educated, and of keeping his own dear tutor on hand to advise and help him. Like most young fathers, Emile refused to consider the fact that babies are firls at least as often as they are boys.

There are a great many obvious faults in the Emile, but for the most part they have been thoroughly criticized. It is apparent at once that is is not a wise plan to educate a child in complete isolation. Nor is it possible to educate many people as Rousseau proposed to educate Emile. A man would have time to educate only one of his sons, and he could not undertake any sort of work until that son was grown. Rousseau does not seem to have intended the system for general application, for he makes Emile the son of a well-to-do father. But on the other hand, we must remember that in Rousseau's day not many peopleugave any thought to general or populareducation. Emile was to have no formal education until he was twelve years old. When he reached that august age he was to be plunged into study, but how he could then learn what it was necessary for him to know Rousseau does not 
explain. He gets around the difficulty by saying that it is not necessary for him to know anything but how to think, but once you grant that, you may as well dispense with formal education altogether. Again, Emile is to be kept in isolation until he is a young man and then plunged into society, seemingly with the hope that he will get more or less disgusted with it at the same time that he is acquiring a society manner. Surely a child educated in such a manner would becextremely awkward the first time he had to be among people. He would be lucky if he excaped an intense aversion for his kind. But what appears to be the crowning folly of the whole thing is the method which is pursued in teaching Emile. He is not to be taught anything he cannot understand or anything he does not wish to know. Hence the tutor is often hard pushed to rouse his interest in a subject which he wishes to teach him, and quite often the poor man is driven to make use of all sorts of artificial contrivances. The best and most farfetched instance of this is the employment of a magician to teach Emmle physics by means of a magnetized toy duck.

On the other hand, by far the greater part of Emile is excellent. The predominant idea in the book is that achild's education should be suitable to his years. This was arnew departure for the eighteenth century, and one that has since been recognized as one of the cardinal principles of education. The fact that Rousseau and modern educators do not agree as to just What was suitable to a child does not make the principle any the less important. Then there are such excellent things as giving 
the child plenty of physical exercise and teaching him to make his own scientific instruments and to draw. All of these things

- have been followed out in modern educational practice with very good results.

Rousseau obviously intended to give in Emile a plan for educating man in such a way as to keep him as natural as possible. This intention was not unconscious. He stated it in the preface to his bools and time after time he harked back to it in the text. Once he declared, and always he worked upon the theory, that the first object of education was to make a man, not a citizen or a social ornament, but a man. Other things might and perhaps would follow, but whether the pupil became anything wlse or not he would be a man. Therefore it was his tutor's task to prepare him to be a man. By man Rousseau must have meant the natural man, the creature who has the common experiences of humanity irrespective of external conditions. The very use of the term would indicate as much. It is the only context in which it is worthy of mention.

Although Rousseau fully realized what he was doing in Eminle, he tells us about it more clearly in two other pieces of writing. The first and most important important of these, the Lettre a Christophe de Beaumont, will be discussed in the following chapter. The second of these writings, Emile and Sophie, is by no means so definite as the Lettre a Christophe de Beaumont. It is a fragment of a novel, in collections of Rousseau's works, printed immediately following Emmle and plainly intended as an 
evaluation of that book. The fragment consists of two letters written by Emile to his tutor and recounting the shipwreck of his marriage and his subsequent adventures. The letters bestow upon the tutor extravagant praise for the way he has equipped his pupil to meet any and all emergencies. Emile has been well educated. When the worst has happened to him, when he has lost all but the humanity which is common to us all, he is still well prepared to meet his condition. The civilized man has lost all but his manhood. We are permitted to see how well his education served him in this predicament.

The first of the two letters tells of the death of Sophle's parents and her little daughter. These events prostrated Sophie with grief and she mourned so- much that Emile began to fear for her health. At length he decided to take her to the capital, in the hope of cheering her. Sophie was unwilling to go, but she finally consented. In Paris the young couple soon gotinto a gay set, and began to drift away from each other in the attempt to escape their mutual grief. The result, inevitable in Rousseau's novels at least, came rather speedily. Sophie confesised a Plagrant infidelity to Emile, who, so far as I am able to discern, was more virtuous only in that he was more discreet. Here we have one result of educating women as Sophie was educated. But Rousseau's position with regard to women was sufficiently illogical to enable him to say that Emiles actions were the result of his education without admitting that Sophie's were influenced by hers. This aspect of the situation does not present itself to him, 
however, and as soon as he can bring himself to believe such a terrible, such an unheard of, such an impossible thing, he leaves the capital immediately. Out of Paris, he works at his trade until he can compose his thoughts and decide what course to follow. After he has thrashed it all out, very calmly for a man so deeply wounded, he determines to leave Paris, France, and Sophie behind him forever. Accordingly he sets out, blindly, without purpose or direction, without money, clothing, or provisions of any kind. To meet his necessities, he works at his trade, and when he cannot find that kind of work he does other things, for his dear tutor has given him the "universal instrument", a phrase which is evidently a somewhat high flown name for a practical education. - Pursuing his course by slow stages he finally arrives at Marseilles and takes ship for Naples, bargaining with the captain to work for his passage. Emfle knows nothing of navigation, but he has been taught enough astronomy to enable him to guess that the ship is not headed for Naples, but for the Barbary coast. But fortunately for the author's purpose, the sky becomes overcast and he is unable to verify his suspicions. These suspicions, however, were well founded, for when they come in sight of land it is the Barbary coast, the ship is boarded by pirates and the passengers are taken prisoners. Emile is held for ransom, but when no ransom is forthcoming after a reasonable length of time, he is sold into slavery. Here he is very happy indeed, so he tells us, for what has he been from his birth but a slave to oonvention? Moreover, he knows how to work, and work well, a circumstance which makes 
him very popular with his masters, and insures him good treatment.

Here ends the second letter, with which Emile et Sophie is concluded in the 1782 edition of Rousseau' works. It is evident, however, from the contents of these two letters and the manner in which they are written that the piece is unfinished. Morley and Davidson both seem to have seen or to know of the existence of a much longer piece, but this I have been unable to find. It is evident from these two letters that the purpose of the work was to follow out the results of Emile's education upon his later life, perhaps simply for the interest of doing it, - perhaps to answer the critics. It is a pity that the thing was not finished. We would like to know what more befalls Emile and whether Sophie's natural goodness reasserts itself. We are not likely to know. But we have seen that which is to us more important--Rousseau's opinion of his system of education. Rousseau may have had some doubts about his success in the education of a woman, but he firmly believed that he had made a $\operatorname{man}$. 
When the Emile was published in 1762 it was greeted with a storm of protest. Within a month the Parlement of Paris condemned the book and ordered that it be burned and its author arrested. It has been thought that some of the author's former friends contributed to this result. The Profession de fol du Vicaire Savoyard furnished the reason for the condemnation, for it antagonized both the orthodox religious party (which included the court) and the rationalistic party (Diderot, D'Alembert, Voltaire, Grimm) who had been attempting to replace religion with reason. "The theology and religion expounded and advocated in Emile, especially in the Savoyard Vicar's Confession of Faith," says Mr. Davidson, "not only set at open defiance all the dogmas of the Church, but were well calculated, by their simplicity and sweet sentimentality, to become widely popular, and undermine the Church's influence. Under the circumstances, we need not be surprised to find that two mutually hostile parties combined to produce the condemnation of Rousseau and his book."

However that may be, and it is by no means certain, although it is extremely probable that this is what happened, on the ninth of June, 1762, the Parlement of Paris was honored by a visit from $\mathbb{M}$. Omei-joly de Fleury, the King's advocate, who brought charges against a newly published book called Emile, ou de I'education. The author, one J-J. Rousseau, had only recently added to his popularity with the people and his 111 repute at 
court by the Contrat Social and the Nouvelle Heloise. Against Emile M. Omer-Joly de Fleury brings six rather interesting charges, five and a half of which, as far as the Court and its advocate were concerned, were a smoke screen thrown out to hide the real reason, which appears in the last half of the sixth charge. The first accusation is that the book was written with a view to restoring natural religion, and that it simply outlined a scheme of education to bring about this end; the second, that the author uses nature as the only guide to morality, and that he holds all religions equally good and equally arising from natural causes; the third, that he limits man to the knowledge instinct gives him, and that he believes one can be saved without believing in God; the fourth, that he attempts to destroy the truth of the scriptures, to question miracles, etc.; the fifth, that he establishes a purely human faith which man is free to accept or reject; the sixth, that to these impieties he adds indecent details which shame modesty and "propositions which tend to give a false and odious character - to the authority of the sovereign, to destroy the principle of obedience which is due him, and to weaken the respect and the love of the people for their kings". The King's advocate concluded by recommending that, the book be condemned and its author prosecuted, and the Parlement obligingly sentenced the book to be torn up and burned, threatened booksellers with appropriate penalties for handling 1t, and ordered the arrest and imprisonment of the author. 
Fortunately the author was warned and fled from France. He would gladly have gone back to Geneva, but here too the Emile was condemned, and along with it the Contrat Social, and a warrant was 1ssued for the arrest of the author if he should set foot in Geneva. Being a prudent man, Rousseau went into the province of Neuchatel and placed himself under the protection of Frederick the Great. Here he found life so pleasant that he remained for three Jearsat a little place called Motiers Travers until, on the departure of the governor, George Kieth, the people rose against him and drove him out. It was while Rousseau was at Motiers that the Archbishop of Paris condemned his work for Catholic reasons and the Attorney General of Geneva condemned it for Protestant ones. It: was here too that he carried on an interesting correspondence with the Prince of Wurtemburg and with others of his admirers, and received the numerous and disturbing visits of his friends and enemies.

Aside from the official condemnation of Paris and Geneva, there were a number of private criticisms of the Emile, chief amomg them, for our purpose at least, and perhaps for any purpose, that of Christophe de Beaumont, the Archbishop of Paris. Such replies to the Emile as have come to my attention have been concerned with the religious views set forth in that book, but Beaumont, in spite of his position, or perhaps because of it, attacks both the 
religious and the educational questions involved. The tone of the whole of $\mathbb{M}$. Beaumont's mandate is that of a narroweand carping criticism. He hasiln several places deliberately given a false idea of Rousseau's remarks, and in general has resorted to very questionable means of gaining his point. Rousseau, on the contrary, answers with a simple dignity unsurpassed in many of his greater works.

The mandate begins with a sweeping denunciation of Rousseau as one who has taken upon himself the duties of a public monitor in order to deceive people and lead them astray. The education of youth is a serious matter for pastors. In order to reform the world as far as the weakness and corruptness of nature will permit, it is necessary to watch forthe first glimmerings of reason and direct them aright. Rousseau proposes a plan of education which, far from. being in accord with Christianity, is not even fit to make either citizens or men. His basic supposition that nature is good and that there is no original sin is without basis in fact or in scripture. Man is driven by a tendency to evil, and how is he to resist it if he is not aided by a vigilant master and does not make great efforts himself? With all the possible aids to virtue, man's mistakes are only too frequent.

1. Beaumont's reply was in the form of a mandate to his priests. 2. Rousseau, v. 25, pp. 366-367

3. p. 367

4. pp. $368-370$ 
Rousseau, Beaumont declares, announces the intention of placing his pupil in a position to choose that religion which the best use of his reason impels him to choose. If Rousseau had only done this, his pupil must have chosen Christianity--for which belief the Archbishop quotes Scripture. But he has not succeeded because, in the attempt to make $\mathrm{h}$ is system of education more palatable to children, he has denuded it of all religion and even of all morality, since he does not think his pupil capable of distinguishing right from wrong. Without doubt judgment is of gradual growth, but it does not follow that a child ten years of age cannot distinguish between good and evil. At that age he will certainly know that it is good to obey his father and bad to disobey him. To pretend anything else, is to slander human nature. Rousiseau says that any child who believes in God is either an idolater or an anthropomorphist. If this is so, it is only because the child is not well taught, and the faults of the teachers should not be attributed to the childoor to religion. Moreover, any child, no matter how well taught, cannot explain himself well. But this benighted Rousseau goes even further. He says that a young man of fifteen years of age is not able to believe in God. He. must surely have a poor opinion of human intelligence and sensibility if he supposes a man could live fifteen years without knowing there is a God. 3

\footnotetext{
1. Rousseau, v. 25, p. 373

2. p. 374

3. pp.374-375
} 
But besides denying his pupil any knowledge of God, he does not even allow him knowledge of himself. He thinks that when his pupil is sixteen he will not eṿen know he has a soul, and he is afraid that if he learns to much he runs the risk of never knowing anything. He does not even wish young people to have a knowledge of their duties, but he wishes the physical strength of his pupil developed and his mind kept idle. This is evidently because he thinks this idleness necessary to dispose the soul to evil; and he evidently postpones teaching morals until his pupil is dominated by passions simply because he hopes that then the pupil will reject. them.

Such a scheme of education as that proposed in the Emile is opposed to the principles of true religion and sound reason. Both desire the watchful care of a wise master over the first glimmerings of intelligence in the pupil, to occupy it with the attractions of truth, and over the first movements of the heart, to fix it with the charms of virtue. It is better to prevent obstacles than to have to surmount them. Moreover, it is to be feared that without this instruction in virtue man will lack courage to resist vice, but a happy experience has shown that after the excesses of an imprudent life, he returns at last to the good principles taught him in childhood. In short, the burden of the mandate is that Rousseau is not a good Christian, and therefore not a good thinker, and for that reason $\mathbb{M}$. Beaumont

1. Rousseau, v. 25 , pp. $376-377$ 
warns his very dear brethren in the Lord to steer clear of him and his works.

Rousseau replies that the fundamental principle of all? . morality, which he has employed in all his books and particularly - In the Emile, is that of the original and natural goodness of man. In other words, there is no original sin; man's natural impulses are good rather than bad, and become bad only through a bad education. A man who has experienced nothing, compared nothing, who has an undeveloped mind, has no conscience, no sense of right or wrong. When he begins to have experiences and to compare ideas, he developes some sense of order, of right and wrong. The Whole object of the Emile has been to provide a system whereby

$\because$ the development of this sense of right shall be facilitated. For this purpose only the proposed system of negative education avails, and that $\mathbb{M}$. Beaumont: would discard because of original sin, forsooth, when he, Rousseau, has just proved to his own satisfaction that there is no original sin.

II. Beaumont objects that men have a sad but natural tendency toward evil, which may not be overcome except under the continual care of pious men. who devote themselves wholly to the eradication of such a fault. Rousseau admits that this is true, but says it is so only because under the existing system they are tyrannized over from birth. Remove this tyranny and give nature a chance to assert itself, and he is confident that nature will

1. v. 11, pp. 24-29 
prove to be all good. It is not man that is at fault. It is the system of education.

\section{"Alas," mourns Beaumont, "in spite of the sanest and} most virtuous principles of education, in spite of the most magnificent promises of religion and the most terrible threats, the faults of youth are only too frequent." Rousseau pounces on the statement with a delight but thinly concealed under his mask of dignity. "I have proved (in the Emile) that that education which you call most sane is the most senseless; that that education which you call most virtuous gives children all their vices; I have proved that all the glory of paradise tempts them less than a lump of sugar." The good Archbishop declares that, left to itself, youth will fall into terrible errors. Rousseau considers that youth is never led away by itself, but that all its mistakes come from being badly handled. Comrades and teachers complete what priests and preceptors have begun. He raises no objection to having education carried on by the priests, provided they accomplish the purpose of education, but he does object to the sort of education that priests and others have been giving children.

Rousseau declares that if man is naturally good, nothing outside of himself can change him, and if he is bad, as he (man) has been at some pains to cause people to believe, his badness comes from somewhere else. How Rousseau reconciled these two views remains somewhat of a mystery. If, he says, the door to 
vice is closed, the human heart will always be good. On this principle he has established the negative education as the best, or rather the only good sort. Positive education he defines as that which tends to give a child knowledge of the duties of the man, and negative education, as that which tends to perfect the organs before giving us this knowledge, and which prepares for reason by the exercise of the senses.

Beaumont has agreed that judgment is a progressive function and is formed only by degrees. But he doubts that at the age of six years the child does not know the difference between good and evil. To that touching bit of his about a child's realizing that to obey his father is good and to disobey him is evil; Rousseau replies that he will feel when he goes from his play to study his lesson in obedience to his father, that to obey his father is bad and to disobey him is good.

Beaumont has charged that to wish not to teach chastity to man until the time when he is dominated by the heat of nascent passions, is to present it to him with the intention that he shall reject it. But Rousseau has already shown that the person who is taught according to his plan will not be governed by passions at the time of which Beaumont speaks. He contends that lessons in chastity could retard the development of these very passions. Up to adolescence he guarantees the heart of his pupil against passions, and when they are about to appear, he still retards their progress by means proper to repress them. Besides, lessons 
in chastity mean nothing to the child, until the age when he takes an interest in and understands them; later they make no impression on a heart already given over to passions.

To the charge that he has removed all principles of religion from his scheme of education in order that the pupil may be more resigned to his other studies, Rousseau replies patiently that he does not think it worth while to teach religion until the child can understand it, and that he does not consider a child under fifteen years of age able to grasp any conception of God. Moreover he believes that the developing intelligence will grasp the notion of divinity without much assistance, and that if this happens, the man is the more likely to retain his religion. He - considers that the thoughtless religion of the average man is idolatrous, and therefore useless to himself and so society.

Beaumont, although basing his attack on the questions - of religion involved in the Emile, nevertheless concerns himself to a great extent with matters fundamental to Rousseau's educational system. He may be regarded as representing the existing educational system as against the proposed one, and the Catholic religion as opposed to naturalism. If Beaumont is viewed in this way, his attack and Rousseau's reply indicate conditions with which Rousseau was faced in his own century and the attitude he took toward them. As to the educational views stated, they are substantially a restatement of those eet forth at greater length In Emile, although they also throw light on the dispute over the 
publication of that book. The views are important from the very way in which they are repeated. Rousseau had realized when he wrote Emile that he was proposing to educate a natural man. He provedilt to Beaumont. First he showed that man was naturally good--stated it, rather, for he offered no proof. To keep him good it was necessary to follow the system ofinegative education outlined in Emile. Keeping him good is the same as keeping him natural--indeed the object is not so much to keep him good as to keep him natural, for what is natural is good. Baldy stated, the argument is somewhat indirect. But we must remember that Rousseau was not stating a new theory. He was answering charges, one by one, in order; each reply cleared up some point in Emile, and the net result was to establish once for all the purpose of Emile. Rousseau believed that by following the course of nature he could keep man natural and good.

The condemnation of Rousseau's books split the Republic of Geneva into two hostile camps, the oligarchic party which had condermed the book, and the opposition, which suggested that perhaps the Savoyard Vicar had a more truly Christian and Protestant ideal than the condemning aristocratic party. To be sure, the strife between the two parties was political rather than theological, and it had been going on for thirty years before anyone had so much as heard of the Emile. Nevertheless they furnished the upper and nether millstones which ground poor Rousseau until he thought there would be nothing left of him. The clergy took sides 
for and against Rousseau, he was be-lettered and be-pamphleted without mercy, and each party sent members of the other party to see just what sort of a man he was, so that not a day passed without his entertaining numbers of visitors.

Among the writings which appeared against Rousseau was Lettres ecrites de la Campagne, the work of Attorney General Tronchin of Geneva. When the fight finally became too hot in 1764 , Rousseau renounced his citizenship in Geneva and answered the opposition with Lettres de la Montagne, written as a direct reply to Tronchin. This work consists of nine letters, unadressed and undated, of which the last four deal with the objections to the Contrat Social. The first five letters of Rousseau's reply deal with the charges brought against him for the Savoyard Vicar's religious opinions. In the first of these letters Rousseau raises the question as to whether a man can properly be condemned for his religious opinions, and shows that the Vicar's philosophy, even if generally adopted, would not be injurious to Christianity or the public welfare. In the second letter he disposes of the ob- jections of the Geneva Protestants, and in the third answers the charge that he is no true Christian because he does not believe in miracles. In the fourth and fifth, which posess little interest for us, he supposes himself guilty and considers the procedure of justice in dealing with his case. He clinches all his argument by declaring that the Savoyard Vicar's Confession was offered, not asea system of religion, but as a method of reasoning with Emile on religious matters. The letters are interesting, and on the 
whole rather well handled, but their only connection with the author's educational philosophy is the fact that they result from attacks on the Emile. It seems that as educational theory Emile was well recelved, but as religious speculation it was condemned almost universally.

Emile made a profound impression on a young German nobleman, the Prince Louis Eugene of Wurtemburg. The Prince had a little daughter about four months old, whom he decided to bring up as Rousseau should direct. He wrote to Rousseau informing him of his intention, but the disappointing Rousseau was not properly thrilled. He replied politely and exasperatingly that he did not pretend to direct the education of princes and princesses. The Prince refused to take the hint. He sent Rousseau full accounts of all the baby did, until Rousseau became interested and drew up plans and gave general advice about the instruction of the child.

\section{Morley mentions a letter of 29 September, 1763, in}

which Rousseau refused to interest himself in the little princess. The earliest letter I have found is one of 17 october, 1763, in which he apologizes for not answering an earlier letter from the Prince, and apologizes in a way that would indicate that the Prince had written a half angry command to pay some attention to his daughter. Rousseau promises to give the matter careful consideration and let him have the results as soon as possible. The next letter comes on 10 November of the same year and is the one outlining the plan for the education of the little Princess. 
As the date would indicate, this letter follows the Emile rather closely. It is interesting to notice that, although he prescribes no studies for the young princess, the education he marks out for her is more like Emile's than like Sophie's. Since the Prince is so unfortunate as to have been born a prince, he will not be able to undertake the education of his daughter, for the education of a child is a task that demands all one's time and attention, and the Prince and his wife will both have social duties in sufficient number to prevent their undertaking anything so.exacting. Hence the child should be given over to the charge of some one, preferably of her own sex. That person ought to be young, but young people usually do not care for this sort of work, - and it will be better to get an older person who does care for it than a younger one who does not. If it is possible to get a woman who has children of her own, so much the better, provided they are not near her. She should have intelligence enough to understand instructions, but not enpugh to refine them. A steady character is always to be preferred to a brilliant one. The only necessary quality is a sense of right. If the governess is ignorant, she may learn as her pupil does. With such initial qualifications for a governess, we may assume that here, as in “ the Emile, the object of education is moral rather than scientific.

With any sort, of a governess, and particularly with this one, three things are necessary for the successful education of a child. First she must love the child. This she might do if she loved its parents, but one may never hope for love from one's 
dependents. Hence it becomes necessary to devise some means of making her care for the child. The best means is self-interest. But she must not have a merely material interest in the welfare of her charge, or she will tend to the apparent needs and neglect the real ones. Her whole fortune must be bound up in the effect of the education she is giving. Then she will see herself in her pupil, and have the necessary affection for her. The governess then will be promised a rich reward if she is successful with her pupil, and no reward at all if she is not successful. Under this system, if she is promised money, it will lose its charm as time passes and she compares the reward with the effort it is to cost her. If the reward is to be money, then, the time for which her services are desired should be broken into several reasonably - short periods, at the end of each of which she will be rewarded for suecess, and dismissed without reward for fallure. But if the reward is not to be money, the period need not be broken, and much happier results will be obtained. A home, property, anything that she is known to desire, may be substituted for money with good effect.

The father is a good person to judge of the effect of education. A mother is likely to be blinded by her feeling for her child, (as if fathers did not suffer from the same complaint), and in any event women have very little judgment. But whoever is to be the judge, it is important that the governess should have entire confidence in him, and that she should realize that she is to be paid not for her trouble but for her success. In any case 
she will get her reward, for no judge would say that a princess fifteen or twenty years old had been badly educated, but she will not realize this, and the important thing is to get the child well educated.

The child will love her governess, especially if she is at first severe, and the child is not spoiled. The child who loves her governess, and knows that the fate of the latter is bound up in the care she gives her, will act as her intelligence and her heart have been taught to act. If at a certain age the little princess is capricious or mischievous, the governess has only to remind her that her own happy old age depends on the good behavior of her charge, and the child will be as good as gold. Any normal child would be, and it is not to be thought that one of such noble blood as the little Princess would be a monster.

The second thing necessary is that the governess have her plan of action all mapped out, and complete confidence in the outcome. She is to be given a memorandum of instructions which she is to learn by heart, so that she knows it "better than an ambassador knows his instructions". But it is much more important that she be convinced that these instructions mark out the only possible way to the goal.

The memorandum should not be given to her just at the beginning. First she should be told what she is expected to do and the state of body and mind she is required to produce in her pupil. On this point no objection can be allowed to her, but she 
must be shown that the plan is feasible, and that it is so only by the means proposed. On this point the master may well reason with her, setting forth his reasons clearly, at length, and in terms she can understand. He must listen to her objections, and discuss them all at length, not for their own sake, but in order to see into her mind. Then the memorandum may be given to her. But the memorandum cannot provide for everything. In the process of educating the pupil, many unexpected things will come up and conferences will be necessary. It is important that these be made so pleasant that she will not hesitate to seek them. These details are particularly the mother's task. She too must know the instructions by heart, but for a different reason. The governess must know them for the rules, the mother for the principles.

The third thing necessary is that the governess have absolute control over the child. This means that the instructions will govern everything. The servants should be informed carefully of the plans for educating the Princess, instructed as to how they are expected to conduct themselves with her, and promised a reward for doing well and dismissal for doing ill.

The child should always be examined with great care. There will always be faults which it has been impossible to prevent, but thich can be corrected if they are taken at once.

It will be noticed, as has been pointed out before, that in this letter Rousseau is still thinking along the same 
line as when he was writing the Emile. Though the letter is by no means either so long or so definite as the Emile, it yet indicates clearly the course Rousseau intended the education of the young Princess to take. The fact that he neither prescribes nor prohibits certain definite studies, and marks out no definite system, as he did in the Emile, simply makes this plan the more elastic, without putting it on a different basis. It is quite evident that here, as in the earlier plan, education is to be moral rather than intellectual. Even with its brevity and its indefiniteness, the plan leaves usseveral points to criticize. It is surprising to learn that "the child will love her governess, especially if she is at first severe." And while it is generally admitted that governesses do teach things they do not understand, still it is not generally expected that governesses are hired with the intention that-they should learn as they teach their pupils. Besides, the Prince was not to educate his daughter because of the pressure of his social duties. Buttby this plan he educates a governess to educate his daughter, and fills in his spare moments by educating the servants to fall in with his plan. Little points like that Rousseau evidently left it to his Royal Highness to solve.

The next letter bears the date 15 December, 1763, and possesses interest both for its content and because it shows how much the Prince was prepared to take from the man he admired. Rousseau writes that he is glad that the Prince proposes to take - charge of the education of his daughter. This makes any advice 
he may have given superfluous. But he is surprised to learn that a man of such rank has the time and inclination for such a task. The Prince thinks his daughter precocious, but Rousseau warns him that fathers have a tendency to regard their children with fond eyes. The Prince has evidently based his conclusion on the fact that she can distinguish between odors and that she has devised a way of making her wants known. Rousseau corforts him with the news that both things are natural and usual. It is unnatural for children to prefer one odor to another, or to cry pettishly, but perfectly natural for them to distinguish between odors, and to announce their desires, since they have noticed that when they cry people attend to them. The Prince thinks she has a good disposition because she likes new people. Rousseau tells him that some people would consider her a coquette, but softens the blow by saying that he thinks it is a sign of character, "for habit is the most certain sign of a weak nature". He warns the Prince that if the child is precocious, she will give him so much the more trouble, and advises him to watch her carefully in order that he. may not apply an unsuitable scheme of instruction.

In the next epistle, dated 21 June, 1764, Rousseau encourages the Prince to bear the criticism of his educational system in patience. There are always old fogies in the world, and what they say ought to serve to show the superiority of his work and encourage him in 1t. He speaks of $\mathbb{M}$. and Mme. Gollowin, who have bravely attempted to rear their child according to his maxims. He says that when he hears of people putting his system to practice, 
he begins to fear that he has made mistakes, for such a system is good only as a whole, and if it is broken off or changed in the middle, the child is spolled for any other system.

On the fifteenth of April, 1764, Rousseau writes that a woman has asked him for advice about her child, that the letter seemed an attempt to discredit his ideas, and that he had told her of the Prince and how he was educating his "petite Sophie". And on the third of september, 1764, he declares that there is nothing more interesting to him than an account of the progress of Sophie. He approves thoroughly of the way the Prince is doing things. It is well to repress acts of authority. The most difficult thing about the scheme of education is to give the child's crying neither more nor less attention than it deserves. He thinks Sophie is going to be artful, and that it will be well if she is, so long as she is not capricious or imperious.

These letters, few and brief as they are, show a continued interest in the subject on the part of Rousseau, the Prince, and other people of less importance. They also indicate that Rousseau is still following the line of the Emile rather closely.

In the Discours sur I'Economie Politique and the Considerations sur le Gouvernement du Pologne et de sa Reformmation Projettee, this contradictory Rousseau sets forth ideas

1. 1758

2. 1772 
diametrically opposed to those he expresses in the Emile. In the Political Economy he says that children should be educated in common by the state, for they are to be citizens, and the state rather than the parents will have to abide by the consequences of their education. Moreover, common education by the state is the best means of training citizens and of teaching children to understand other people and to live in society. In other words, the object here is to make citizens. In the Emile it is to make men.

In the Considerations on the Government of Poland, citizenship is again the object of education. This discourse is written not as pure theory, but as a practical scheme for the actual government of Poland. National education is only for free men. French, Itallans, Russlans, Spanish, English, are all alike. At twenty years of age a citizen of Poland ought to be just that and nothing else. When he learns to read, he should read about his country so that at ten years he knows all its products, at twelve, all the provinces, roads, and towns, at fifteen, all its history, and at sixteen, all its laws. The law ought to regulate the matter, the order and the form of their studies, and they ought to be taught by Poles, all married, if possible, all distinguished for their morals, their probity, their good sense, and their intelligence. Teaching should be made a public office so that only men of the highest type enter 1t. Rich and poor, noble and commoner, should be educated together and without any distinction being made between them. They are all citizens. Every school should have a gymnasium and children should play together under the supervision of the 
teachers. Parents who prefer to educate their children at home should be compelled to send them to take part in these games. Education should be under the control of a board of magistrates, who can appoint, change and remove the heads of schools at will. The heads of the schools may be promoted to the board of magistrates, and the instructors to the principalship, if they deserve such promotion. This is the system best calculated to make good teachers.

This system, unlike that advocated in the Emile, is clearly intended for general application. It has the advantage over the earfier system in that it permits the child more natural development in the society of other children. Its weakness lies in the absolute ironclad control of the state. But we must remember that this is not educational metaphysics, so to speak. It is a practical system designed for the express purpose of making good citizens for Poland. And we must not forget that while this book did not have the direct influence on the development of modern educational theory that the Emile had, nevertheless it was the forerunner of the national school system of France, of public education in America, and of free school education in England and Germany. While in none of these countries the state system is compulsory, in all of them the great number of people, and in America of people of every class and condition, are educated together in the public schools. This does not mean that Rousseau had any influence on the movement. So far as I know, nobody, from 1772 until the present date has discovered that he ever said any such 
things about education, for the simple reason that they have read nothing but Emile. I am simply pointing out that he said such things a quarter of a century before the movement began. 